\title{
Effect of Austenitization Temperature on the Precipitation of Carbides in Quenched Low Carbon Boron Steel
}

\author{
C. A. Suski · C. A. S. Oliveira
}

Received: 21 November 2012/Revised: 13 December 2012/Accepted: 19 December 2012/Published online: 3 January 2013

(C) Springer Science+Business Media New York and ASM International 2013

\begin{abstract}
The objective of this study was to study the effect of austenitization temperature on the formation of carbide/borocarbide, the microstructure and the mechanical properties of low carbon boron steel after quenching and its effects on the tensile properties of the steel. Three austenitization temperatures were used: 870,1050 , and $1200{ }^{\circ} \mathrm{C}$. The steel microstructures were analyzed by light, scanning and transmission electron microscopy techniques. Microstructural analyses showed that the highest percentage of martensite was obtained at the austenitizing temperature of $1050{ }^{\circ} \mathrm{C}$. The lower content of martensite at the austenitization temperature of $870{ }^{\circ} \mathrm{C}$ was caused by the low percentage of boron in solution or by the largest nonequilibrium segregation of boron to the grain boundaries at $1200{ }^{\circ} \mathrm{C}$. A lower content of borocarbide $\left(\mathrm{Fe}_{23}(\mathrm{C}, \mathrm{B})_{6}\right)$ was identified for the austenitization of $1050{ }^{\circ} \mathrm{C}$, which caused an enhanced effect of boron on the reducing of the formation of carbide/borocarbide on the grain boundaries.
\end{abstract}

Keywords Boron segregation - Low carbon boron steel · Precipitation · Quenching

\section{A. Suski $(\bowtie)$}

Instituto Federal de Santa Catarina, Rua 3122, n. 340 Apto 901, Balneário Camboriú, SC CEP 88330-290, Brazil

e-mail: cassio_suski@hotmail.com

\section{A. S. Oliveira}

Mechanical Engineering Department, Universidade Federal de Santa Catarina, Campus Universitário, Post Office Box 476, Florianópolis, SC 88040-900, Brazil

e-mail: carlos.a@ufsc.br

\section{Introduction}

Quenched and tempered low carbon boron steel has been used for many different applications, such as in automotive, furniture, domestic electric appliance, construction, petroleum, agriculture, and transport industries. Small additions of boron substantially increase the hardenability of low carbon steels, due to the segregation of boron to the boundaries of austenitic grains [1].

The enrichment of solute atoms in grain boundaries is due to either equilibrium or non-equilibrium segregation phenomena. Equilibrium segregation occurs by the diffusion of solute atoms to the atomic layers of grain boundaries at the austenitization temperature [2, 3]. The adsorption of solute atoms at the grain boundary reduces the interfacial free energy.

Non-equilibrium segregation is a dynamic process that occurs during cooling from high temperatures, resulting in a wider solute-enriched zone with a width that depends on the cooling rate. The enrichment is the result of mobile vacancy-solute complexes diffusing down the vacancy gradients toward vacancy sinks [3-5]. The equilibrium concentration of vacancies in the steel increases with temperature, and rapid cooling forms the vacancy gradient necessary for boron to segregate to the austenitic grain boundaries.

Non-equilibrium and equilibrium segregation can occur simultaneously; however, the concentration profiles and the dependencies of these processes on time and temperature are quite different which allows the effects to be distinguished.

The segregation of boron in low carbon steels has a behavior similar to that shown in Fig. 1, which in this case depicts segregation in the INCONEL 718 alloy [6]. It can be observed that the austenitization temperature affects the 
segregation of boron to the austenitic grain boundaries in various ways, i.e., the equilibrium segregation decreases as the temperature increases (curve A), while the non-equilibrium segregation behaves oppositely and increases with temperature (curve B). The total boron segregation (curve C) exhibits a transition temperature, below which equilibrium segregation predominates, and above which, non-equilibrium segregation prevails. In addition to the transition points shown in Fig. 1, the temperature may vary as a function of the chemical composition of the studied material and the cooling rate.

According to several authors, there is a maximum limit to the boron segregation-induced formation of borocarbides $\left(\mathrm{Fe}_{23}(\mathrm{C}, \mathrm{B})_{6}\right)$; this limit specifically applies to the precipitation of borocarbides along austenitic grain boundaries, which have a tendency to act as the preferred site for ferrite nucleation events $[3,7]$. The upper limit is a function of the alloying elements and the processing parameters, such as the austenitization temperature and the cooling rate. Therefore, the segregation of boron and the precipitation of borocarbide must be controlled to avoid the nucleation of ferrite.

The total boron segregation, from which the $\mathrm{Fe}_{23}(\mathrm{C}, \mathrm{B})_{6}$ can occur, is lower at higher austenitization temperatures because the total grain boundary area is relatively small due to the increased grain size. However, the increased segregation of boron over the grain boundary may increase the precipitation of borocarbides due to both the reduction in grain boundary area and the increase of total boron segregation by non-equilibrium segregation processes [8-10].

The objective of this study was to study the effect of the austenitization temperature on the precipitation of carbides/ borocarbides, on the microstructure and on mechanical properties of low carbon boron steel after quenching; additionally, this work aimed to correlate the microstructures with the mechanical properties of the obtained low carbon boron steels.

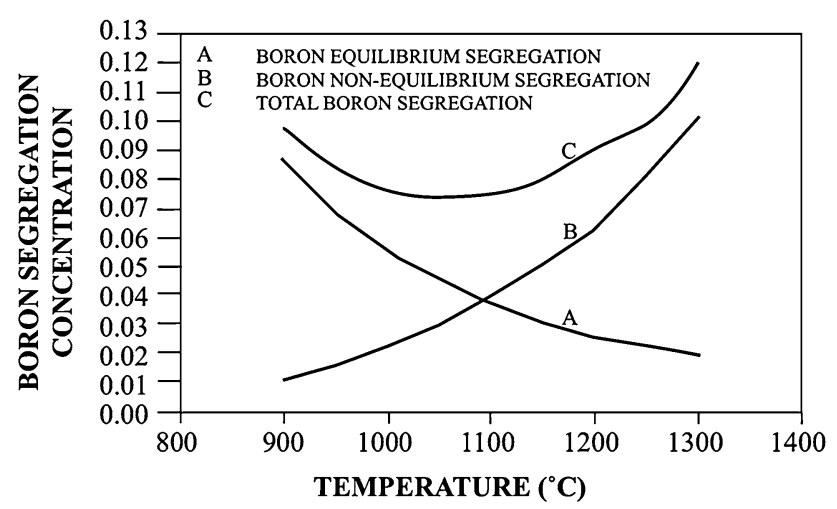

Fig. 1 The effect of temperature on the concentration of boron at the austenitic grain boundaries [6]

\section{Experimental Procedure}

The material studied was a low carbon boron steel that had been rolled and wire drawn to a diameter of $14.30 \mathrm{~mm}$, and the chemical composition is shown in Table 1 . In its original state, the steel microstructure was identified by metallography as a combination of ferrite and coalesced carbides. Steel quenching was carried out at three different austenitization temperatures: 870,1050 , and $1200^{\circ} \mathrm{C}$ at a soaking time of $30 \mathrm{~min}$ and with oil cooling at $80^{\circ} \mathrm{C}$.

The microstructural characterization of the quenched steel was made by light microscopy (LM), scanning electron microscopy (SEM) with energy-dispersive $\mathrm{x}$-ray spectroscopy (EDS), and transmission electron microscopy (TEM). The etching reagent was Nital $2 \%$.

The phases were quantified by the point-counting method, which utilized a mesh overlay on the sample with at least 20 points per sample, as identified from the SEM micrographs.

The chemical composition was analyzed by EDS, which was carried out in precipitates identified by SEM imaging. In this case, the EDS analysis is presented qualitatively due to the low atomic weight of boron, which impairs its identification in a more robust quantitative manner.

The TEM analyses were carried out with high-resolution imaging of carbon replicas. The use of carbon replicas allows the matrix effect to be isolated, which in turn allows for the specific analysis of precipitates by electron diffraction. The carbon replicas were generated with a sputter coater (metallizer); the samples were subjected to a posterior removal with the Nital 5\% solution and were then mounted onto a copper grid.

The high-resolution images were obtained from carbon replicas of the precipitates. Inverse Fourier transform analyses were applied to these images, which resulted in a mask that generated an enhanced resolution of the diffracted crystal planes and enabled more accurate measurements of the interplanar distances of the precipitates through the use of Digital Micrograph software. Identification of the precipitates was performed by comparing the measured interplanar distances against standards that have been published in the literature [11].

The precipitate sizes were measured directly from the images obtained by SEM and TEM; the measurement software package used was Image J $1.39 \mathrm{u}$.

The mechanical properties were determined through uniaxial tension testing. The tension tests were carried out

Table 1 The chemical composition of the low carbon boron steel

\begin{tabular}{llllllll}
\hline $\mathrm{C}(\%)$ & $\mathrm{Mn}(\%)$ & $\mathrm{P}(\%)$ & $\mathrm{S}(\%)$ & $\mathrm{Si}(\%)$ & $\mathrm{Al}(\%)$ & $\mathrm{Cr}(\%)$ & $\mathrm{B}(\%)$ \\
\hline 0.20 & 1.088 & 0.011 & 0.007 & 0.240 & 0.036 & 0.156 & 0.0027 \\
\hline
\end{tabular}


at room temperature on a DL-20000 universal assay machine at $0.3 \mathrm{~mm} / \mathrm{min}$ according to ASTM A-370 standard. The values reported here are a mean of three tests.

\section{Results and Discussion}

Figure 2 shows the typical microstructures of the samples processed according to the three austenitization temperatures $\left(870,1050\right.$, and $\left.1200{ }^{\circ} \mathrm{C}\right)$. All conditions yielded a mixed microstructure of martensite laths and granular bainite. Table 2 shows the variation in the percentage of martensite and bainite as a function of the austenitization temperature.

Figures 3 and 4 show images of the precipitates with average sizes of 15 and $55 \mathrm{~nm}$ as measured by SEM and carbon replica TEM, respectively.

Both borocarbide $\left(\mathrm{Fe}_{23}(\mathrm{C}, \mathrm{B})_{6}\right)$ and cementite were identified. The borocarbide $\left(\mathrm{Fe}_{23}(\mathrm{C}, \mathrm{B})_{6}\right)$ precipitates were measured to sizes of $55 \pm 3 \mathrm{~nm}$ for the austenitization temperature of $870{ }^{\circ} \mathrm{C}$ (Figs. 3a, 4a) and $15 \pm 2 \mathrm{~nm}$ for the austenitization temperatures of $1050{ }^{\circ} \mathrm{C}$ (Figs. 3b, 4b)
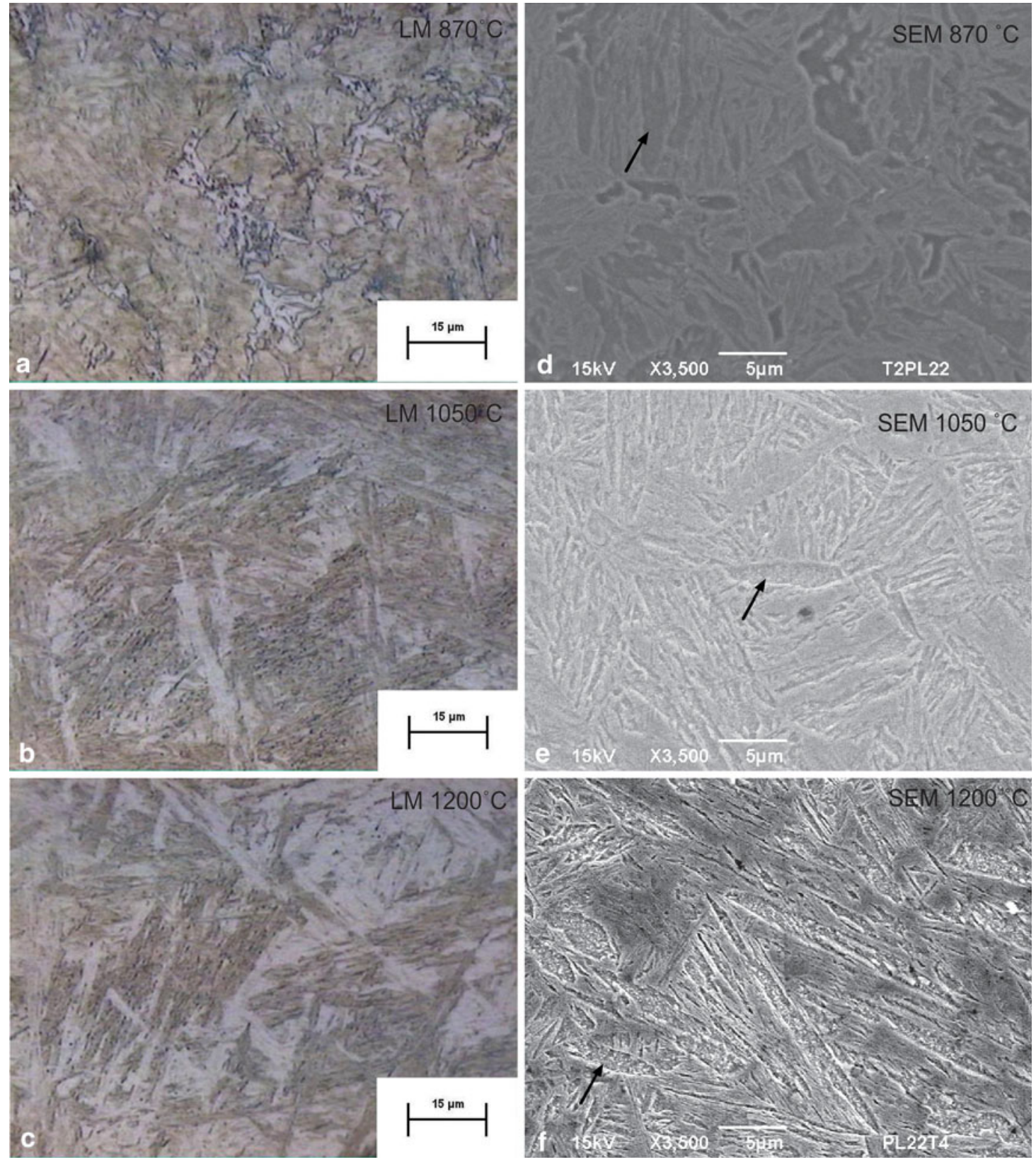

Fig. 2 The microstructures of the quenched samples, which were composed of martensite and bainite, as found by LM (a-c) and SEM (d-f). a, d $870{ }^{\circ} \mathrm{C}$; b, e $1050{ }^{\circ} \mathrm{C}$; $\mathbf{c}, \mathbf{f} 1200{ }^{\circ} \mathrm{C}$. The arrows indicate the presence of granular bainite 
Table 2 The variation of the percentages of martensite and bainite as a function of the austenitization temperature

\begin{tabular}{llrr}
\hline & $870{ }^{\circ} \mathrm{C}$ & $1050{ }^{\circ} \mathrm{C}$ & $1200{ }^{\circ} \mathrm{C}$ \\
\hline Martensite (\%) & $86 \pm 1.2$ & $94 \pm 1.8$ & $74 \pm 2.3$ \\
Bainite (\%) & $14 \pm 1.2$ & $6 \pm 1.8$ & $26 \pm 2.3$ \\
\hline
\end{tabular}

and $1200{ }^{\circ} \mathrm{C}$ (Figs. 3c, 4c). The cementite $\left(\mathrm{Fe}_{3} \mathrm{C}\right)$ presented with sizes of $30 \pm 3 \mathrm{~nm}$ for all three conditions.

Figure 5 shows an EDS spectrum of a precipitate in Fig. 3(a), where the presence of iron, carbon, and boron are all found, indicating that this is likely $\mathrm{Fe}_{23}(\mathrm{C}, \mathrm{B})_{6}$.

Figure 6 shows an EDS spectrum obtained for another precipitate in Fig. 3(a), where iron, carbon, and manganese are all identified and boron was not. Therefore, this precipitate is likely cementite $\left(\mathrm{Fe}_{3} \mathrm{C}\right)$.

In Fig. 7, the presence of $\mathrm{Fe}_{23}(\mathrm{C}, \mathrm{B})_{6}$ can be identified in the sample austenitizated at $1050{ }^{\circ} \mathrm{C}$. This precipitate phase was also found in the samples austenitizated at 870 and $1200{ }^{\circ} \mathrm{C}$. Figure 8 shows the presence of cementite $\left(\mathrm{Fe}_{3} \mathrm{C}\right)$ in the sample austenitizated at $870{ }^{\circ} \mathrm{C}$. Cementite was also identified in the samples austenitizated at 1050 and $1200{ }^{\circ} \mathrm{C}$.

Figure 7 (a) and (b) shows the borocarbide $\left(\mathrm{Fe}_{23}(\mathrm{C}, \mathrm{B})_{6}\right)$ that was found for the austenitization temperature of $1050{ }^{\circ} \mathrm{C}$. Figure $7(\mathrm{c})$ and (b) show high-resolution images of borocarbide with and without the mask, respectively. Figure 7(d) depicts the Fourier transform applied to obtain (e). The measured interplanar distances are shown in Fig. 7 (from $\mathrm{f}_{1}$ to $\mathrm{f}_{5}$ ) and are equal to $1.797 \AA, 2.044$ and $2.031 \AA$, and 2.369 and $2.368 \AA$. Those distances correspond to the $[1,3,5](d=1.792 \AA),[1,5](d=2,037 \AA)$ and $[4,2,0]$ $(d=2.367 \AA)$ planes of borocarbide $\left(\mathrm{Fe}_{23}(\mathrm{C}, \mathrm{B})_{6}\right)$, respectively.

Figure 8(a) shows carbide $\left(\mathrm{Fe}_{3} \mathrm{C}\right.$ ), and Fig. 8 (from $\mathrm{b}_{1}$ to $\mathrm{b}_{2}$ ) displays the corresponding interplanar distances, which are equal to 2.391 and $2.077 \AA$. These distances correspond to plans $[2,1,0](d=2.390 \AA)$ and $[1,0,2](d=2.074 \AA)$ of cementite. Figure $8(\mathrm{c})$ depicts the Fourier transform applied to obtain the interplanar measurements.

The results of the uniaxial tension tests of the quenched samples tested at austenitization temperatures of 870, 1050, and $1200{ }^{\circ} \mathrm{C}$ are shown in Fig. 9. It can be observed that the yield points overcome a rather small drop at the austenitization temperature of $1050{ }^{\circ} \mathrm{C}$ versus the temperature of $870{ }^{\circ} \mathrm{C}$ and within the standard deviation. An increase in the tensile strength can be identified for the samples processed at $1050{ }^{\circ} \mathrm{C}$ versus those processed at $870{ }^{\circ} \mathrm{C}$. At the austenitizing temperature of $1200{ }^{\circ} \mathrm{C}$, it was observed that the yield point and the tensile strength values are lower than those of the samples austenizated at 870 and $1050{ }^{\circ} \mathrm{C}$.
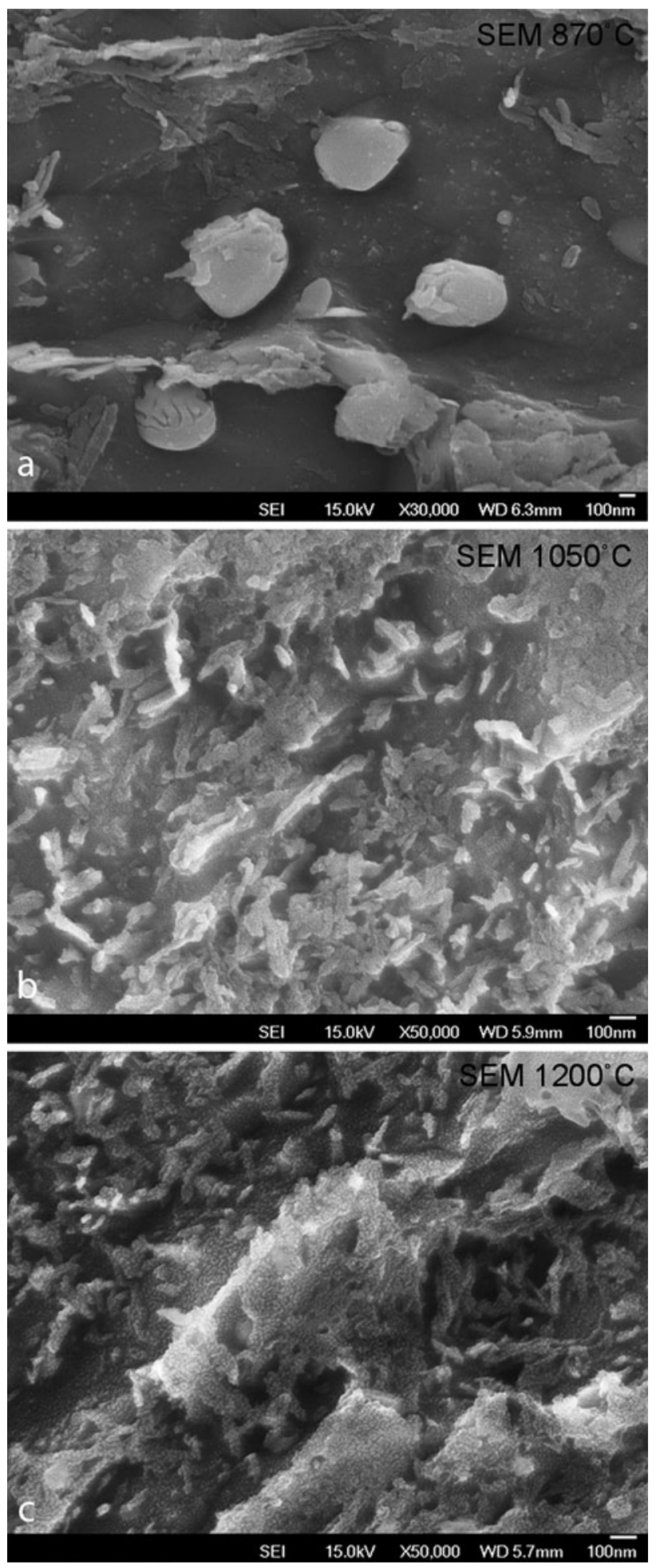

Fig. 3 The precipitates found by SEM at the austenitization temperatures of: a $870{ }^{\circ} \mathrm{C}$, b $1050{ }^{\circ} \mathrm{C}$, and c $1200{ }^{\circ} \mathrm{C}$

The microstructural analyses demonstrated that the precipitates and the size of the precipitates that resulted from quenching are directly related to the austenitization temperature. These precipitates have a direct influence on 

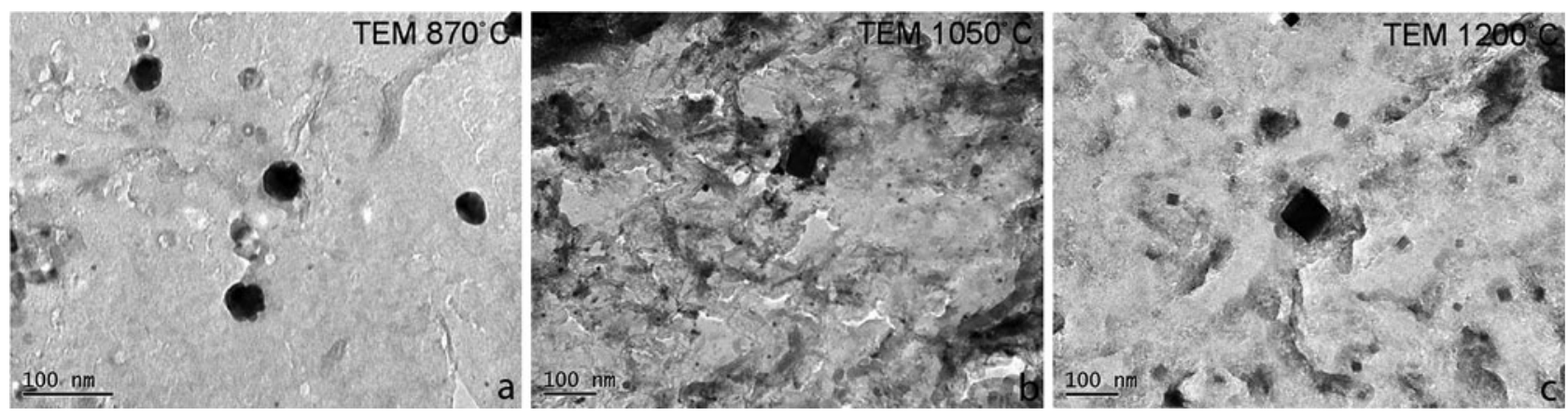

Fig. 4 Images of the carbon replicas of the quenched samples identified by TEM. a $870{ }^{\circ} \mathrm{C}, \mathbf{b} 1050{ }^{\circ} \mathrm{C}$, and $\mathbf{c} 1200{ }^{\circ} \mathrm{C}$

Fig. 5 The EDS spectrum of a precipitate in Fig. 3(a), possibly identified to be borocarbide $\mathrm{Fe}_{23}(\mathrm{C}, \mathrm{B})_{6}$
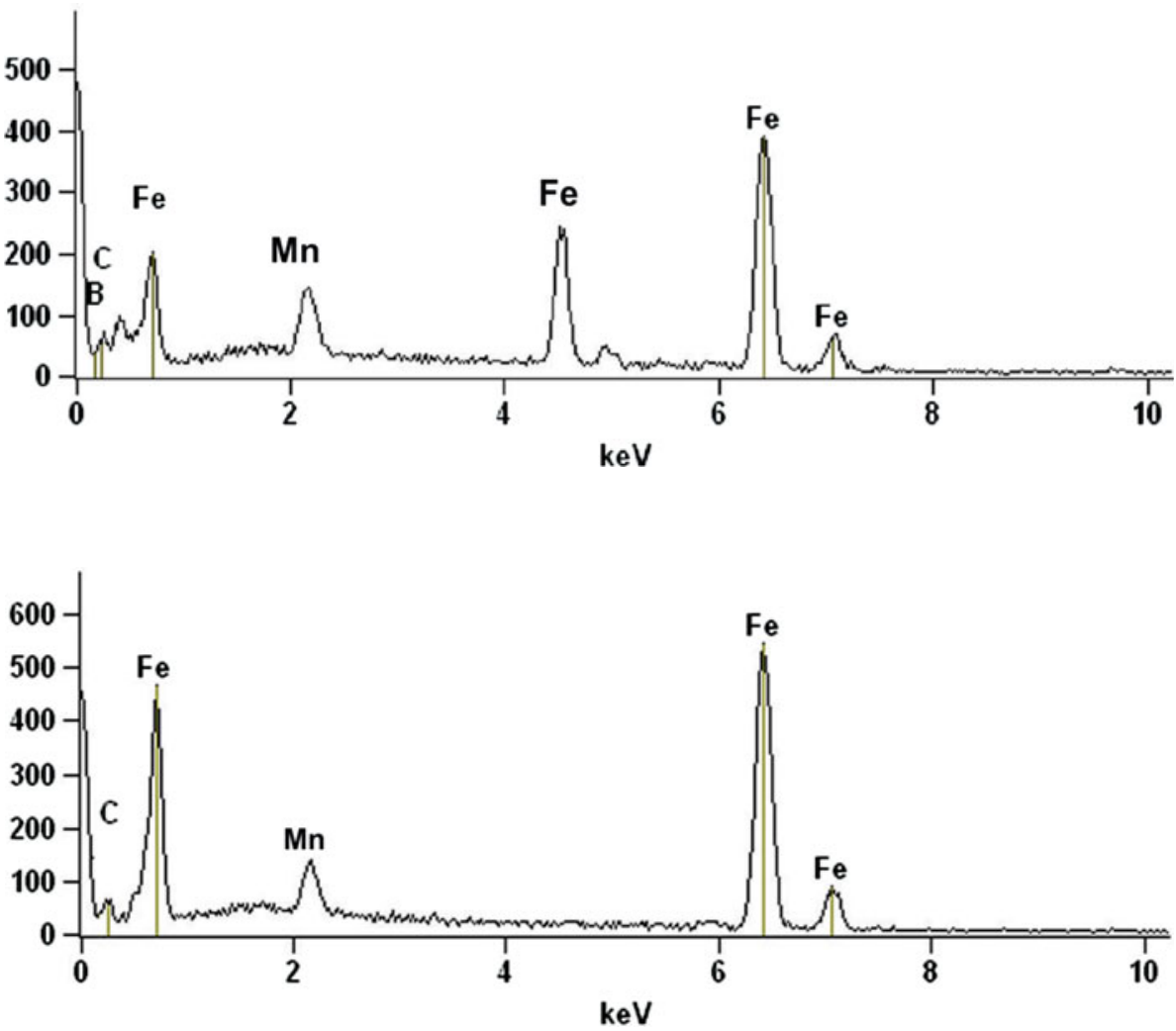

Fig. 6 The EDS spectrum of a precipitate in Fig. 3(a). This precipitate is likely cementite, $\mathrm{Fe}_{3} \mathrm{C}$ and above $1200{ }^{\circ} \mathrm{C}$ (Fig. 3c, 4c), the borocarbide precipitates solubilize and re-precipitate during quenching, yielding reduced precipitate sizes of $15 \pm 2 \mathrm{~nm}$. The presence of both borocarbides $\left(\mathrm{Fe}_{23}(\mathrm{C}, \mathrm{B})_{6}\right)$ and cementite $\left(\mathrm{Fe}_{3} \mathrm{C}\right)$ was also documented by Hwang et al. [3] and Han et al. [7] in low carbon boron steels.

The presence of $\mathrm{Fe}_{3} \mathrm{C}$ at the three austenitization conditions (Figs. 3, 4, 8), with an average size of $30 \pm 3 \mathrm{~nm}$, indicates that solubilization and re-precipitation occurred, due to the either self-tempering of martensite or formation of bainite [13]. Additionally, the larger size of the borocarbides at the austenitization temperature of $870{ }^{\circ} \mathrm{C}$ and the high martensite start temperature $\left(M_{\mathrm{s}}\right)$ of the low carbon steels both support the re-precipitation of cementite $[12,14]$. 


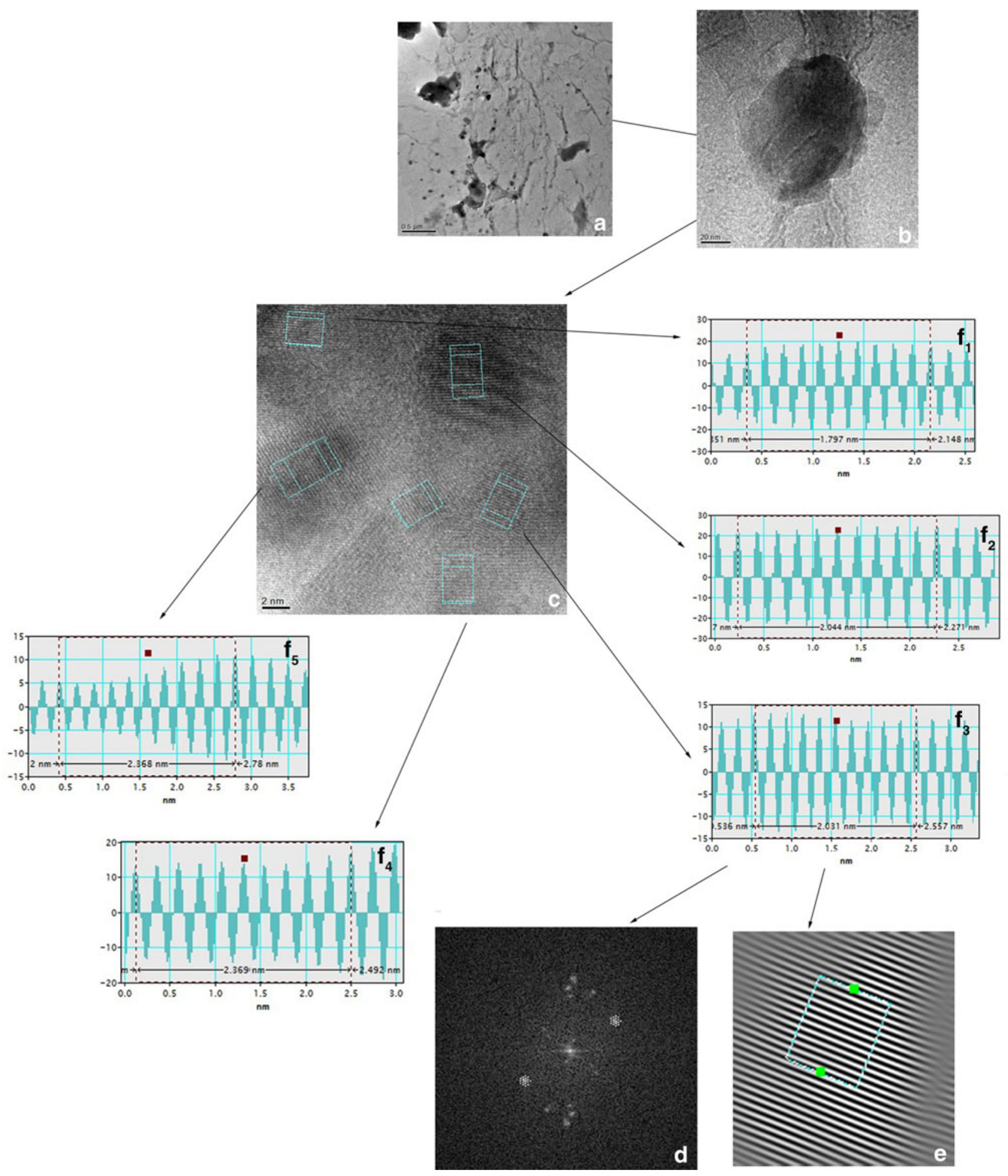

Fig. 7 A high-resolution image of $\mathrm{Fe}_{23}(\mathrm{C}, \mathrm{B})_{6}$ at the austenitization temperature of $1050{ }^{\circ} \mathrm{C}$. a The carbon replicas, $\mathbf{b}$ a precipitate at $1050{ }^{\circ} \mathrm{C}$,

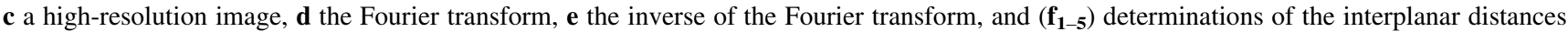

The austenitization temperature of $870{ }^{\circ} \mathrm{C}$ is below the solubility of $\mathrm{Fe}_{23}(\mathrm{C}, \mathrm{B})_{6}$, which prevents the segregation of boron to the grain boundaries; however, the $\mathrm{Fe}_{23}(\mathrm{C}, \mathrm{B})_{6}$ precipitates coalesce and this increases the interfacial energy of the grain boundaries and reduces the effect of boron segregation on the steel hardenability [12].

Comparing the borocarbides formed at the austenitization temperatures of 1050 and $1200{ }^{\circ} \mathrm{C}$, more precipitation/ 


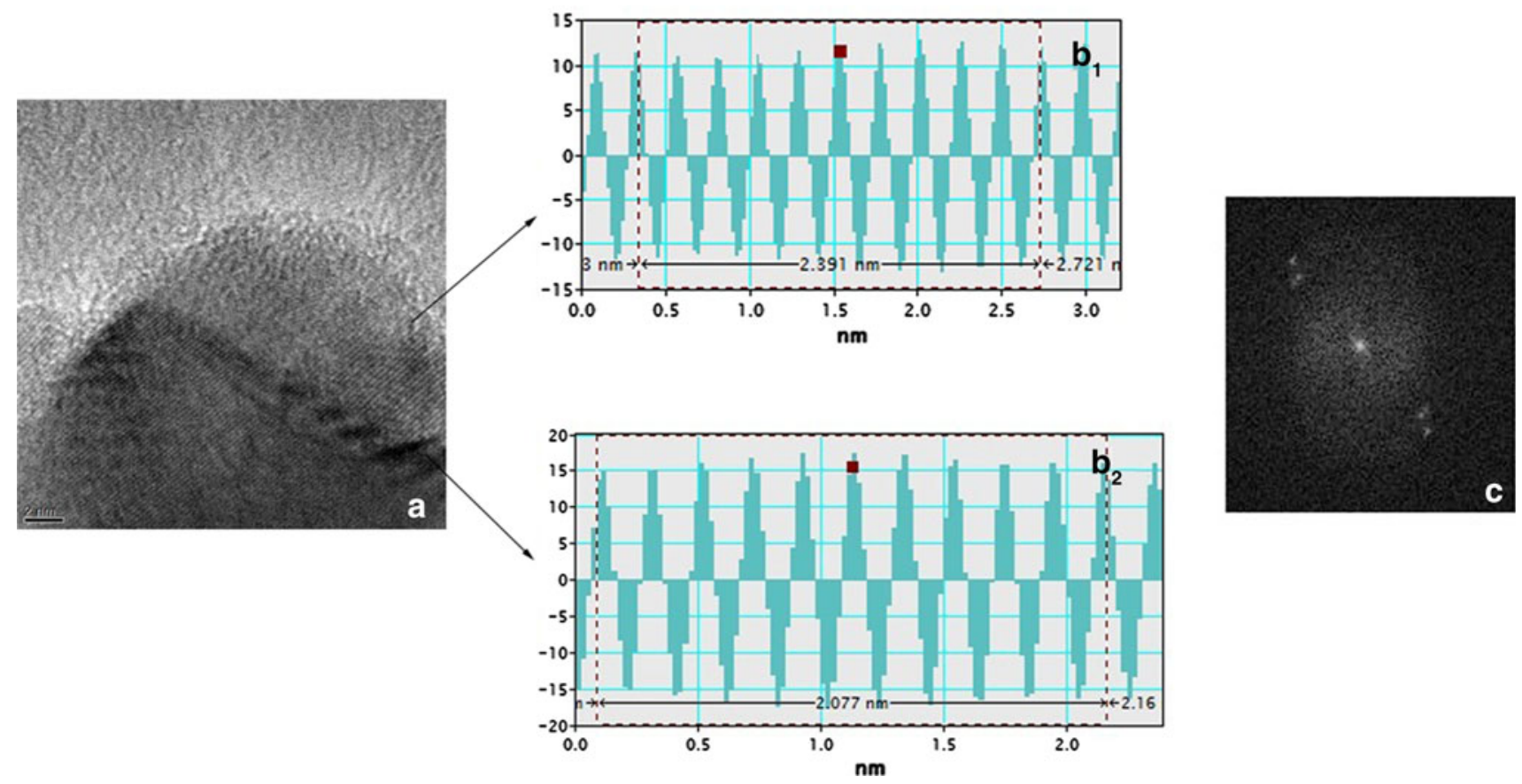

Fig. 8 A high-resolution image of the $\mathrm{Fe}_{3} \mathrm{C}$ at the austenitization temperature of $870{ }^{\circ} \mathrm{C}$. a The high-resolution image, (b $\left.\mathbf{b}_{1-5}\right)$ the interplanar distances, and $\mathbf{c}$ the Fourier transform

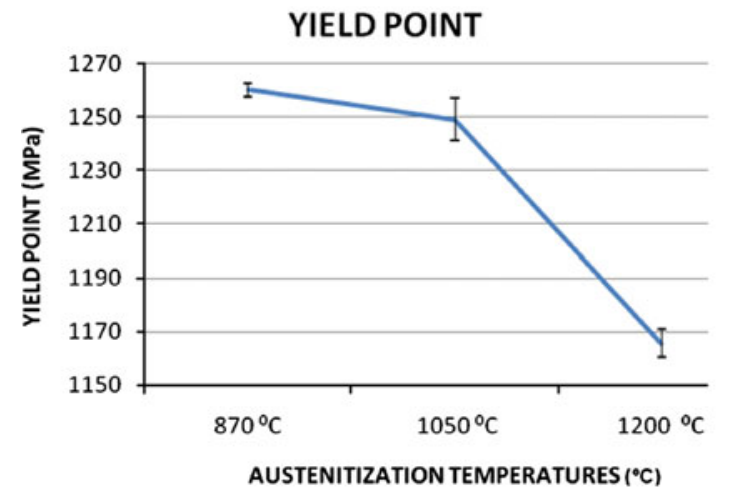

AUSTENITIZATION TEMPERATURES $\left({ }^{\circ} \mathrm{C}\right)$

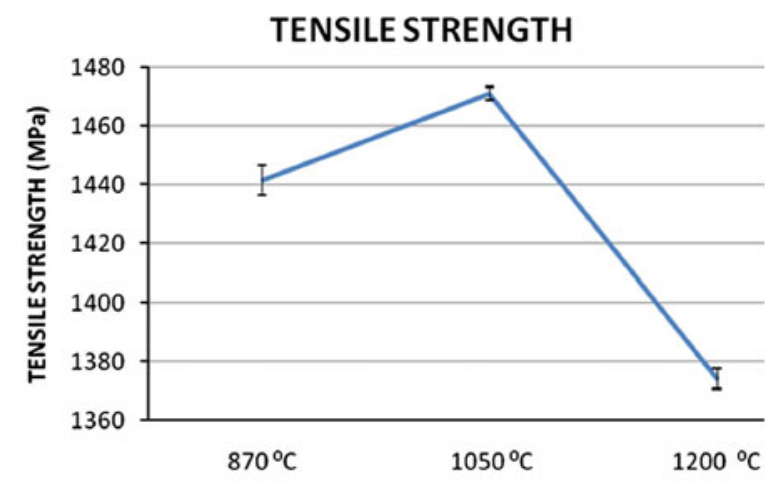

AUSTENITIZATION TEMPERATURES $\left({ }^{\circ} \mathrm{C}\right)$

Fig. 9 The yield point and the tensile strength values at the austenitization temperatures of 870,1050 , and $1200{ }^{\circ} \mathrm{C}$

re-precipitation can be found at the grain boundaries of the steel processed at the temperature of $1200{ }^{\circ} \mathrm{C}$. This is shown in Fig. 1 as an increase in non-equilibrium segregation, which favors the precipitation of borocarbide on grain boundaries; this phenomenon occurs at the temperature of ferrite formation during quenching and reduces the steel hardenability.

Another important factor is the corresponding increase in grain size as the austenitization temperature is increased. The increase in grain size decreases the grain boundary area, and the reduction in grain boundary area increases the total boron concentration of the boundary, which also favors a higher precipitation of borocarbide at the austenitization temperature of $1200{ }^{\circ} \mathrm{C}[13,15,16]$.
As shown in Fig. 9, the increase in austenitization temperature causes a small reduction in the value of the yield point (within the standard deviation) at $1050{ }^{\circ} \mathrm{C}$ and a greater reduction at $1200{ }^{\circ} \mathrm{C}$. These results may be due to two concurring effects. First, the austenite grain size, which increases with the austenitization temperature has a tendency to reduce the yield point. Second, the percentage of martensite, which further increases the yield point $[13,15]$. The small reduction in yield point with the variation of austenitization temperature from 870 to $1050{ }^{\circ} \mathrm{C}$ may be due to these two effects because at $1050{ }^{\circ} \mathrm{C}$, there is a higher percentage of martensite and a greater austenitic grain size compared to the steel processed at $870{ }^{\circ} \mathrm{C}$. The greater reduction in the yield point at the austenitization 
temperature of $1200{ }^{\circ} \mathrm{C}$ versus that of the other two austenitization temperatures is due to the increased grain size and the reduced percentages of martensite.

The tensile strength of the steel, as a function of austenitization temperature, decreases in the following temperature order: 1050,870 , and $1200{ }^{\circ} \mathrm{C}$, Fig. 9. This behavior is related to the percentage variation in the martensite at these experimental conditions. The variation in the austenite grain size has little effect on the tensile strength, as observed by other authors $[13,15]$. The coalesced borocarbides in austenitizated steels at $870{ }^{\circ} \mathrm{C}$ and the higher precipitation of borocarbide at the grain boundaries of the steel processed at $1200{ }^{\circ} \mathrm{C}$ reduced both the percentage of martensite and the tensile strength.

Table 3 shows a summary of the variables analyzed as functions of the austenitization temperature. As discussed previously, it can be observed that the borocarbides $\left(\mathrm{Fe}_{23}(\mathrm{C}, \mathrm{B})_{6}\right)$ do not dissolve but instead coalesce at the austenitization temperature of $870{ }^{\circ} \mathrm{C}$, presenting increased sizes when compared to the borocarbides precipitates formed at the other austenitization temperatures. The presence of borocarbide increases the free energy of the austenitic grain boundaries and reduces the effect of boron on the hardenability, which further reduces the percentage of martensite and the tensile strength and increases the bainite percentage.

At 1050 and $1200{ }^{\circ} \mathrm{C}$, the borocarbides $\left(\mathrm{Fe}_{23}(\mathrm{C}, \mathrm{B})_{6}\right)$ are dissolved and re-precipitated during cooling and quenching (self-quenched), presenting smaller sizes compared to the precipitates of the austenitization temperature of $870{ }^{\circ} \mathrm{C}$. The lower precipitate content at $1050{ }^{\circ} \mathrm{C}$ compared to $1200{ }^{\circ} \mathrm{C}$ is due to the reduced total and non-equilibrium segregation of boron, which increases the percentage of martensite, subsequently increasing the tensile strength and the yield point.

Table 3 A comparison of the variables analyzed in relation to the austenitization temperature

\begin{tabular}{llll}
\hline & $870{ }^{\circ} \mathrm{C}$ & $1050{ }^{\circ} \mathrm{C}$ & $1200{ }^{\circ} \mathrm{C}$ \\
\hline $\mathrm{Fe}_{23}(\mathrm{C}, \mathrm{B})_{6}$ & Coarse & $\begin{array}{c}\text { Fine/lower } \\
\text { amount }\end{array}$ & $\begin{array}{c}\text { Fine/greater } \\
\text { amount }\end{array}$ \\
$\mathrm{Fe}_{3} \mathrm{C}$ & Present & $\begin{array}{c}\text { Present } \\
\text { Present }\end{array}$ & $\downarrow$ \\
Martensite & $\downarrow$ & $\uparrow$ & $\uparrow$ \\
Bainite & $\uparrow$ & $\downarrow$ & $\downarrow$ \\
Yield point & $\uparrow$ & $=\downarrow$ & $\downarrow$ \\
$\quad$ Escoamento & & $\uparrow$ & $\downarrow$ \\
Tensile strength & $\downarrow$ & & $\downarrow$ \\
Resistência & & $\uparrow$ & \\
Hardenability & $\downarrow$ &
\end{tabular}

$\downarrow$ Reduction of the observed variable

$\uparrow$ Increase of the observed variable

$=\downarrow$ Approximately equal or small reduction of the observed variable

\section{Conclusion}

The microstructural variations and the behavior of mechanical properties as a function of the austenitization temperature were studied in this article. These studies were performed on samples of a low carbon boron steel. Based on the results of this study, the following conclusions can be stated:

The presence of an increased content of coarse borocarbides, $\mathrm{Fe}_{23}(\mathrm{C}, \mathrm{B})_{6}$, at an austenitization temperature of $870{ }^{\circ} \mathrm{C}$ occurred because the borocarbides coalesced instead of dissolving at this austenitization temperature.

There is a lower content of borocarbide $\left(\mathrm{Fe}_{23}(\mathrm{C}, \mathrm{B})_{6}\right)$ precipitates for the austenitization temperature of $1050{ }^{\circ} \mathrm{C}$. This is caused by a reduction in the total and non-equilibrium segregation of boron to the grain boundaries, which reduces the free energy of the grain boundaries and avoids the nucleation of ferrite.

The precipitation of borocarbide $\left(\mathrm{Fe}_{23}(\mathrm{C}, \mathrm{B})_{6}\right)$ increases with the increase in austenitization temperature from 1050 to $1200{ }^{\circ} \mathrm{C}$. This increase is related to the increase in total boron concentration in the austenitic grain boundaries, which occurs as the result of non-equilibrium segregation and reduces the steel hardenability. The reduction in hardenability caused by the borocarbide increases the percentage of bainite. The precipitation of borocarbides at these temperatures occurs during quenching (selfquenched), i.e., the precipitate is first dissolved and then re-precipitates during cooling when the corresponding quenching temperature is reached.

The microstructural analysis shows that the highest percentage of martensite is obtained at the austenitization temperature of $1050{ }^{\circ} \mathrm{C}$. For the austenitization temperature of $870{ }^{\circ} \mathrm{C}$, the lowest amount of martensite can be identified; this is attributed to the low percentage of boron in solution. At $1200{ }^{\circ} \mathrm{C}$, the largest non-equilibrium boron segregation to the grain boundaries occurs, as indicated by the precipitation of borocarbides.

The presence of borocarbide and cementite can be found for all austenitization conditions. However, the precipitated amounts vary as a function of the austenitization temperature.

The results of the mechanical property analyses (yield point and tensile strength) show significant correlations between the values obtained in the tests and the percentage of martensite and the presence of borocarbides.

The yield point decreases with increasing austenitization temperature. The yield point is slightly reduced (within a standard deviation) as the temperature is increased from 870 to $1050{ }^{\circ} \mathrm{C}$, and the reduction at $1200{ }^{\circ} \mathrm{C}$ is greater. These results are attributed to two concurring effects. The austenite grain size, which increases with the austenitization temperature, has a tendency to reduce the yield point, 
in addition to the percentage of martensite, which increases at $1050{ }^{\circ} \mathrm{C}$ and decreases at $1200{ }^{\circ} \mathrm{C}$.

The higher tensile strength observed for the austenitization temperature of $1050{ }^{\circ} \mathrm{C}$ in relation to the other austenitization temperatures is mainly related to variations in the percentage of martensite. The variation of austenite grain size had little effect on the tensile strength.

Acknowledgments The authors would like to acknowledge the technical staff of the Central Laboratory of Electron Microscopy (LCME) at the Universidade Federal de Santa Catarina for their contribution to the development of this project.

\section{References}

1. J.E. Morral, T.B. Cameron, A model for ferrite nucleation applied to boron hardenability. Metall. Trans. A 8(11), 1817-1819 (1977)

2. M. Jahazi, J.J. Jonas, The non-equilibrium segregation of boron on original and moving austenite grain boundaries. Mater. Sci. Eng. A 335(1-2), 49-61 (2002)

3. B. Hwang, D.W. Suh, S.J. Kim, Austenitizing temperature and hardenability of low-carbon boron steels. Scripta Mater. 64(12), 1118-1120 (2011)

4. X.L. He, Y.Y. Chu, J.J. Jonas, The grain boundary segregation of boron during isothermal holding. Acta Metall. 37(1), 147-161 (1989)

5. L. Karlsson, H. Norden, Grain boundary segregation of boron. An experimental and theoretical study. J. Phys. Colloques 47(C7), 257-262 (1986)

6. X. Huang, M.C. Chaturvedi, N.L. Richards, J. Jackman, The effect of grain boundary segregation of boron in cast alloy 718 on
HAZ microfissuring-A SIMS analysis. Acta Mater. 45(8), 3095-3107 (1997)

7. F. Han, B. Hwang, D.W. Suh, Z. Wang, D.L. Lee, S.J. Kim, Effect of molybdenum and chromium on hardenability of lowcarbon boron-added steels. Met. Mater. Int. 14(6), 667-672 (2008)

8. X.X. Yao, On the grain boundary hardening in a B-bearing 304 austenitic stainless steel. Mater. Sci. Eng. A 271(1-2), 353-359 (1999)

9. D.J. Mun, E.J. Shin, Y.M. Koo, A study on the behavior of boron distribution in low carbon steel by particle tracking autoradiography. Nucl. Eng. Technol. 43, 1-6 (2011)

10. D. Lin, Y. Zhang, A theoretical investigation on non-equilibrium grain boundary segregation. Mater. Sci. Eng. A 256(1-2), 39-50 (1998)

11. S. Ahmed, J.M. Titchmarsh, M.R. Kilburn, C.R.M. Grovenor, Examination of the influence of boron on the microstructure and properties of low $\mathrm{C}$ ferritic steels using NanoSIMS and TEM. Appl. Surf. Sci. 252(19), 7062-7065 (2006)

12. S.J. Casarin, Characterization of the hardenability of a microalloyed C-Mn steel to boron, and by dilatometry curves of phase transformations for continuous cooling. Doctoral Thesis, USP, São Carlos, 1996

13. C.A.S. Oliveira, Direct hardening low alloy steels: kinetic aspects, microstructural and mechanical properties, Doctoral Thesis, COPPE-UFRJ, Rio de Janeiro, 1994

14. M. Paju, Effects of boron protection method on properties of steel. Ironmaking Steelmaking 19(8), 495-500 (1992)

15. S.H. Song, A.M. Guo, D.D. Shen, Z.X. Yuan, J. Liu, T.D. Xu, Effect of boron on the hot ductility of 2.25Cr1Mo steel. Mater. Sci. Eng. A 60(1-2), 96-100 (2003)

16. X.M. Wang, X.L. He, Effect of boron addition on structure and properties of low carbon bainitic steels. ISIJ Int. 42(Supplement), S38-S46 (2002) 